STUDII

\title{
O PROBLEMĂ SIMPLĂ, COMPLICATĂ DE JURISPRUDENȚĂ: NATURA JURIDICĂ A DOCUMENTAȚIILOR DE URBANISM (PUG, PUZ, PUD)
}

DOI: $\quad 10.24193 /$ SUBBiur.65(2020).1.4

Data publicării online:

13.04.2020

Ovidiu Podaru*

Rezumat: O problemă importantă a dreptului urbanismului cu care s-a confruntat în ultimii ani jurisprudența noastră, a fost aceea de a stabili natura juridică a documentaţiilor de urbanism (planul urbanistic general - PUG, planul urbanistic zonal - PUZ și planul urbanistic de detaliu - PUD). Sunt ele acte normative sau dimpotrivă, au un caracter individual? Importanța practică a chestiunii este vizibilă din două puncte de vedere: pe de o parte, potrivit regulilor contenciosului administrativ, actele normative pot fi atacate oricând în justiție, fără o limită în timp, în vreme ce pentru actele individuale este instituit un termen de prescripție de șase luni. Pe de altă parte, doar în cazul actelor individuale este obligatorie chemarea în judecată, alături de organul emitent, și a beneficiarului actului, sub sancțiunea respingerii cererii ca inadmisibilă.

În prezentul studiu am ajuns la concluzia că cele trei tipuri distincte de documentații de urbanism au, în mod necesar, una și aceeași natură juridică: sunt acte administrative normative. Am pornit analiza acestei situații de la criteriul de distincție dintre cele două categorii fundamentale de acte administrative: este vorba despre un criteriu calitativ - determinabilitatea destinatarilor actului, iar nu despre

* Conferențiar universitar doctor la Facultatea de Drept a Universităţii Babeș-Bolyai din ClujNapoca. Acesta a fost subiectul de discuție al autorului la Conferința Națională de Contencios administrativ. Ediția specială de Transilvania (UJ), organizată la Cluj-Napoca în 13 noiembrie 2019. 
unul cantitativ - numărul acestor destinatari. Documentațiile de urbanism sunt acte normative pentru că toate au destinatari determinabili - orice persoană care dorește să construiască pe suprafața reglementată de actul în cauză. În plus, documentațiile de urbanism întrunesc toate criteriile necesare pentru considerarea lor ca fiind acte normative, criterii propuse acum mai bine de un secol de unul dintre părinții dreptului administrativ francez - Gaston Jèze: ele creează o situație juridică generală, permanentă și la care nu se poate renunța. În plus, doar identitatea de natură juridică poate justifica posibilitatea ca cele trei tipuri de documentații de urbanism să se poată modifica sau abroga unele prin altele.

Cuvinte cheie: Documentații de urbanism, plan urbanistic general - PUG, plan urbanistic zonal - PUZ, plan urbanistic de detaliu - PUD, act administrativ normativ, act administrativ individual.

În ultimii zece ani a apărut, parcă de nicăieri, un curent jurisprudențial potrivit căruia anumite documentații de urbanism (în anumite situații PUZ și, aproape întotdeauna PUD) au fost considerate acte administrative individuale. Pentru un teoretician al dreptului administrativ, un asemenea curent stârnește cel puțin îngrijorare: pentru că distincția dintre actele normative și cele individuale reprezintă unul dintre pilonii de susţinere ai acestei ramuri de drept, aplicarea lui greșită (fie din neînțelegerea exactă a distincției, fie dintr-un soi de comoditate declanșată de unele dintre consecințele sale - bunăoară termenul de prescripție al acțiunii în contencios administrativ îndreptată împotriva actelor individuale - nu poate avea, pe termen lung, decât consecințe dramatice: fie o jurisprudență inconsecventă, fie una greșită care, la final, va distruge (măcar în parte) structura de rezistență a dreptului administrativ.

Este motivul pentru care, în studiul care urmează ne-am propus să aşezăm într-un raţionament logic toate argumentele în scopul readucerii lucrurilor pe făgașul lor normal: toate documentațiile de urbanism (PUG, 
PUZ, PUD, regulamentele locale - RLU) au fost, sunt și rămân acte normative. $\mathrm{Cu}$ toate consecințele care decurg de aici.

$\mathrm{Cu}$ această idee stabilită drept scop, după ce vom analiza distincția dintre cele două categorii de acte și consecințele acesteia (1), vom face aplicarea acesteia la situația (particulară a) documentațiilor de urbanism (2).

1 Distincția între actele administrative normative și individuale, la nivel teoretic, și consecințele acesteia

Orice distincție ori categorisire teoretică, pentru a fi riguroasă și serioasă trebuie, pe de o parte, să se fundamenteze pe un criteriu exact, căci altfel există riscul unor erori majore (1.1); pe de altă parte, trebuie să existe consecințe juridice importante între categoriile formate căci altfel distincția în cauză riscă să cadă în derizoriu (1.2).

1.1 O posibilă sursă a erorii jurisprudențiale: criteriul calitativ versus criteriul cantitativ

Atunci când o noțiune juridică este încadrată greșit, într-o clasificare prestabilită, aproape întotdeauna, eroarea vine din necunoașterea ori înțelegerea greșită a criteriului de distincție care fundamentează clasificarea în cauză. Cel mai probabil așa s-a întâmplat și în această situație: criteriul calitativ („determinabilitatea” destinatarilor) a fost înlocuit cu false criterii. Le vom analiza pe toate în continuare. 
1.1.1 Criteriul calitativ (veritabil): determinabilitatea destinatarilor unui act administrativ

a) Enunțarea criteriului. Așa cum am menționat şi într-o lucrare anterioară, apărută acum zece ani ${ }^{1}$, diferența între cele două categorii fundamentale se face în funcție de determinabilitatea persoanelor cărora li se aplică actul administrativ: un act normativ („regulament”) are o aplicabilitate generală, asupra unui număr nedeterminat de persoane (dar determinabil ulterior, în mod progresiv, la momentul/momentele de aplicare concretă a actului), pe când actul individual (sau, mai exact, nereglementar/nenormativ) produce efecte asupra unui număr determinat de subiecți de drept ${ }^{2}$ (și, adesea, relativ restrâns). Cu alte cuvinte, actul normativ reglementează secundum legem sau, altfel spus, organizează aplicarea legii, vizând toată societatea sau numai o categorie determinată de persoane, pe când actul individual aplică în concret legea, la diferite persoane (una sau mai multe) determinate. Clasificarea „acte normative - acte individuale" are așadar drept punct de referință particularii cărora li se aplică actul - „destinatarii” sau „adresanții” acestuia - (subiecți

${ }^{1}$ Ov. Podaru, Drept administrativ, Vol. I Actul administrativ. Repere pentru o teorie altfel, Ed. Hamangiu, Bucureşti, 2010, pag. 58.

2 În plus, în doctrina franceză se foloseşte şi criteriul complementar ce ține de obiectul actului: actul normativ are ca obiect modificarea ordonanțării juridice generale, în vreme ce actul individual urmărește stabilizarea unei situații juridice precise în favoarea unui beneficiar. Pentru detalii, a se vedea R. Chapus, Droit administratif général, $13^{e}$ éd, tome I, Montchrestien, Paris, 1999, pag. 524-525, P. AUvERT, La notion de droit aquis en droit administratif français, în Revue de droit public et de la science politique, 1985, pag. 67. În realitate, acest criteriu este același, însă puțin altfel formulat: pe de o parte avem cadrul normativ general (setul de reguli aplicabil fără a avea unul au mai mulți destinatari nominalizați), pe de alta, avem acești beneficiari individuali care dobândesc drepturi subiective prin actul care îi nominalizează. 
determinabili sau determinați), și nu alte criterii care, adesea, în mod eronat au fost invocate:

- $\quad$ formulările abstracte sau precise pe care le conține actul,

- $\quad$ identificarea unui număr extrem de restrâns de destinatari,

- $\quad$ sau, de ce nu (dacă ne gândim la problema care ne interesează), întinderea unei suprafețe de teren avută în vedere de conținutul actului în cauză.

Așadar, mai clar formulată această idee, ea se rezumă la următoarele aspecte:

(i) că determinabilitatea vizează întotdeauna persoanele și nu altceva (bunăoară categoria din care fac parte acestea, care, în mod evident, ar putea fi... determinată(!), fără ca asta să afecteze natura actului respectiv);

(ii) că ea este un element calitativ, nu cantitativ: „determinabil” echivalează cu „normativ”; „determinat” echivalează cu „individual”;

(iii) că ea se apreciază la momentul emiterii actului administrativ, iar nu ulterior, la momentul aplicării efective și concrete a actului în cauză când, în mod evident toți subiecții devin determinați de vreme ce doar aşa se poate aplica în concret un act administrativ.

b) Clarificarea termenilor: „determinabil” versus „determinat”. Chiar dacă enunțarea unui criteriu de distincție s-ar face extrem de clar, o eroare ar putea persista dacă aceasta și-ar avea sursa în greșita înțelegere a conceptelor utilizate. Tocmai de aceea se impun clarificări suplimentare.

(i) Termenul „determinabil” presupune în primul rând apartenența subiecților de drept la un anumit grup sau o anumită categorie de persoane (de exemplu: funcționari publici, pietoni, şoferi, studenți, primari, 73 
Președintele României, bugetari, pensionari, proprietarii de terenuri ș.a.). Desigur, este posibil ca această categorie să fie una extrem de largă, la nivel social: cetățenii, persoanele majore, toate persoanele fizice ori, juridice și, în fine, cea mai largă categorie posibilă - toți subiecții de drept. Prin apartenența la această categorie, cei vizați de conținutul actului sunt identificabili ulterior, adică la momentul la care se pune problema aplicării unei anumite norme la o anumită persoană: dacă aceasta are calitatea stabilită de actul normativ sau face parte din grupul de persoane vizat de acesta, spunem că el are vocația de a-i fi aplicabil actul în cauză ${ }^{3}$. Dar, la fel de bine, ar putea fi o categorie extrem de restrânsă, cu un singur element identificabil la un moment dat: oare cum am putea susține că orice fel de reglementare, fie ea lege ori act administrativ normativ care îl vizează pe Avocatul Poporului ar fi un act administrativ individual, iar nu unul normativ, pentru simplul fapt că, astăzi, la momentul la care scriem aceste rânduri, ea i se aplică exclusiv ... dnei Renate Weber? În realitate orice asemenea reglementare - act normativ fără discuție - are un grad general de aplicare: ea vizează orice persoană care ar ocupa această funcție, în perioada în care actul este în vigoare, identitatea ipoteticilor destinatari fiind irelevantă pentru eficacitatea acestui act.

3 Bunăoară, o reglementare care vizează „toți funcționarii” Administrației Naţionale de Meteorologie i se aplică lui X tocmai pentru că... el este un asemenea funcționar!!! Pe de altă parte, faptul că într-un anumit moment (azi, 20 ianuarie 2020, ora 20.20) pot fi identificați toți funcționarii acestei autorități publice, să zicem în număr de 76 persoane, nu transformă reglementarea respectivă într-un act individual, căci problema nu se poate pune într-o asemenea manieră. Astfel, informația că toți destinatarii actului sunt cunoscuți este falsă: nu aceștia (cei 76) sunt singurii asemenea destinatari, ci toți cei care, în intervalul de timp cât actul a fost în vigoare, au avut calitatea de funcționari ai A.N.M. Or, acest lucru poate fi, eventual, stabilit, doar la momentul la care actul a ieșit din vigoare, în vreme ce interesul stabilirii naturii juridice a unui act administrativ se pune la momentul intrării sale în vigoare, cum am arătat deja, respectiv vom dezvolta ulterior. Iar în acest moment, destinatarii actului sunt doar determinabili, prin apartenența la categoria în cauză. 
(ii) Pe de altă parte, termenul „determinat” impune nominalizarea subiectului de drept; iar nominalizarea expresă echivalează cu „specificarea in mod concret, pe numet" a destinatarului actului administrativ (adică particularul căruia i se aplică actul este indicat în mod expres, cu nume, prenume, CNP, domiciliu sau orice alte elemente care permit identificarea lui corectă și exactă - aşa-numitele „date cu caracter personal”). Prin urmare, un act administrativ individual va avea întotdeauna determinat subiectul (sau subiecții) de drept în chiar cuprinsul actului, prin simpla lecturare a acestuia putând fi identificat acest destinatar, fără a mai fi necesari alți pași suplimentari de identificare a persoanei (de pildă, o decizie de numire în funcție a unui funcționar public X („Popescu George”), o hotărâre a Universității de acordare a unei burse de merit către studenții A și B („Marin Ionescu” și „Ion Marinescu”), o autorizație de construire emisă în favoarea Clubului CFR Cluj etc.). Așadar, actul individual întotdeauna își cunoaște destinatarii la momentul emiterii sale, spre deosebire de cel normativ care, aşa cum am arătat, va avea întotdeauna doar destinatari determinabili prin stabilirea unei categorii abstracte de subiecți de drept, categorie mai largă ori mai restrânsă; deci, pentru a putea vedea cui i se aplică la un anumit moment dat un asemenea act trebuie ca subiecții de drept să fie trecuți prin filtrul apartenenței la categoria reglementată (de pildă: o hotărâre de guvern, de stabilire a unui mod concret de calculare a pensiilor - toți cei care au calitatea

4 Conform DEX: „nominaliza, nominalizez, vb. I. Tranz. A indica, a denumi, a specifica ceva în mod concret, pe nume.” ACADEMIA ROMÂNĂ Institutul DE LiNGVISTICA „IORGU IORDAN - AL. RoSETTI”; AVRAM Larisa, Zorela CREȚA, Corina GHEORGHE, Anca GHERMAN, Daniela GRĂDINESCU, Eugenia Guțulescu, Irina Koch, Lucreția Mareș, Georgeta Mitran, Eleonora PoPA, Silvia SĂvUlESCU, Ariadna ȘTEFăNESCU, Radu TRIF et Romana TulbuRE (dir.), Dicționarul explicativ al limbii române: DEX, Univers Enciclopedic, București, 2016, p. 794 la termenul „nominaliza”. 
de pensionari, „Regulamentul Facultății de Drept”- toți studenții acesteia, respectiv toate cadrele didactice, în funcție de prevederile regulamentului în cauză etc).

„Nominalizarea” presupune aşadar întotdeauna o indicare expresă, în cuprinsul actului, „a persoanei „în carne și oase”, nu doar a categoriei din care face parte ${ }^{5}$." Altfel spus, nu este suficient ca subiectul de drept să fie identificabil („determinabil” - chiar dacă această operațiune ar fi una extrem de facilă!), ca actul să fie individual, ci acesta trebuie să fie identificat (,determinat”) în cuprinsul actului final, (a identifica o persoană în cuprinsul documentaţiei care a stat la baza emiterii actului este, aşa cum vom arăta mai jos, o capcană, un asemenea act nefiind unul individual). De pildă, o autorizație de construire este individuală pentru că beneficiarul este indicat cu nume și prenume în cuprinsul actului, nefiind suficient a se menționa că dreptul de construire este conferit proprietarului, iar proprietarul s-ar putea identifica în vreun fel din cuprinsul documentației (din cererea de obținere a autorizației, din menționarea numelor în avizele obținute etc.).

\subsection{Un pseudo-criteriu sau o confuzie regretabilă: criteriul cantitativ}

Din toate cele arătate mai sus, se poate aşadar observa că numărul concret al persoanelor cărora li se aplică un act normativ, respectiv individual,

\footnotetext{
5 Tocmai de aceea, atunci când această persoană dispare (fizic sau juridic, în funcție de natura ei), trebuie să ne punem serios problema caducității actului individual: acesta este strâns legat de persoana destinatarului său, așa că, atunci când acesta din urmă dispare, actul individual își încetează de regulă efectele: o diplomă de studii, un act de numire în funcţie, un act de sancționare etc. Numai în mod excepțional și în ipoteza unui text de lege expres dreptul sau obligația creată printr-un act individual se transmite la succesorii acestuia. Dimpotrivă, este de esența actului normativ să nu fie afectat în niciun fel prin dispariția unui subiect de drept față de care actul în cauză s-ar aplica la un moment dat.
} 
este irelevant, criteriul de distincție nefiind unul cantitativ, ci unul calitativ. Așa cum s-a arătat și în doctrina franceză ${ }^{6}$, generalitatea normelor nu exclude personalizarea efectelor (la un moment dat), în situația în care norma se aplică, la acel moment la care se pune problema calificării naturii actului, unui unic titular posibil care ar avea calitatea determinată prin norma în cauză. Reamintim, un act administrativ normativ nu se transformă într-unul individual chiar dacă, în concret, se aplică unei singure persoane7: de pildă, Capitolul II al Titlului III din Constituție - „Președintele României” rămâne un act normativ, deși, în orice moment privit izolat, nu se aplică decât unei singure persoane, acea care ocupă funcția în acel moment ${ }^{8}$. La polul opus, un act administrativ individual nu se transformă într-unul normativ chiar dacă el vizează sute de persoane (de pildă, o hotărâre UNBR referitoare la

${ }^{6}$ B. SEILLER, Droit administratif 2. L'action administrative, ed. 2, Ed. Champs Université, p. 136-137.

7 ibidem, p. 137. Autorul francez dă exemplul actului care determină atribuțiile Prefectului Senei, act care rămâne reglementar (normativ), chiar dacă, în orice moment ales în concret, el se aplică doar titularului de moment al funcției. Actul nu îl vizează pe acesta ca persoană fizică, unică, ci pe el și toți cei care îl vor succeda în funcție (până la abrogarea actului administrativ). Obiectul actului, ținând de atribuțiile funcției, produce efecte față de orice persoană care ar ocupa acea funcție, nu doar față de titularul actual.

8 Ov. PODARU, op. cit., nota 1, p. 6o, n. 5. Sau, dacă ne gândim la prevederile art. 107 din Constituție („Primul-ministru”) putem înțelege realitatea acestui raționament: (1) faptul că azi acest text i se aplică unei anumite persoane nu înseamnă deloc că mâine i se va aplica aceleiași persoane, ori cine va fi acea persoană și (2) oricine poate spera să ajungă în această funcție și, deci, ca textul să i se aplice pentru o perioadă de timp. Acelaşi raționament se aplică și în situația mai sus indicată a Avocatului Poporului, organizarea și funcţionarea acestuia fiind reglementate de L: 35/1997 (publicată în M.of.: 48/20.03.2017 şi republicată în M.of:: 181/27.02.2018): chiar dacă legea se aplică, în mod concret, azi, doar unei singure persoane (cea care ocupă funcția de Avocat al Poporului - dna Renate Weber), legea nu își epuizează efectele prin faptul că în viitor o altă persoană va ocupa această funcție, fiindu-i aplicabilă, în consecință, și acesteia. Iar acest lucru nu poate fi explicat decât prin faptul că actul în cauză este unul normativ. 
persoanele care au fost admise sau respinse în profesia de avocat). Mai mult, efectele unui act administrativ normativ pot fi în viitor individualizate (o singură persoană poate intra în câmpul de aplicare al normei, la un moment precis), desemnarea abstractă a subiecților de drept permițând de asemenea ca, una sau mai multe persoane, care nu sunt identificabile la momentul emiterii actului, să intre în câmpul de aplicare al normei la momentul la care vor dobândi acea calitate (de pildă, o hotărâre de guvern care afectează modul de calcul al pensiilor se va aplica, în viitor, și persoanelor care la momentul emiterii ei nu au calitatea de pensionari, dar vor dobândi ulterior această calitate). Este tocmai ideea de „determinabil”, despre care am vorbit de la început. Însă actul administrativ cu caracter individual se distinge de cel cu caracter normativ tocmai prin faptul că presupune o individualizare, o particularizare a efectelor încă de la momentul emiterii lui: el urmărește aplicarea în concret a unei norme (reguli) preexistente (fie că este vorba despre lege sau act administrativ cu caracter normativ), pentru un caz particular, vizând un anumit destinatar nominalizat expres.

În ce privește criteriul ,întinderii efectelor juridice pe care le produce actul” despre care vorbește ÎCCJ, în unele hotărâri, atunci când analizează natura juridică a actelor administrative, chiar dacă acesta pare a sugera un criteriu cantitativ, în realitate, din ansamblul argumentelor instanței noastre supreme rezultă în mod clar ideea unui criteriu calitativ: „În funcție de întinderea efectelor, actele administrative se clasifică în acte normative și acte individuale. Actele administrative normative conțin reglementări cu caracter general, impersonale, care produc efecte erga omnes, în timp ce actele individuale produc efecte, de regulă, față de o persoană, sau uneori față de mai multe persoane, nominalizate expres în conținutul acestor acte /s.n., Ov.P.] [...] or, din această perspectivă, rezultă cu puterea evidenței că actul 
administrativ în discuție, HG nr. 349/2005, este unul normativ din moment ce conține reguli generale, de aplicabilitate repetată, iar destinatarii sunt un număr indeterminat de subiecți9.”[s.n. Ov.P.]

\subsection{Consecințele calificării unui act administrativ ca fiind normativ} sau, după caz, individual: diferența de regim juridic între situația juridică generală (creată de un act normativ) și cea particulară (creată de un act individual). Cele 4 criterii propuse de Gaston Jéze

Acum mai bine de un secol, celebrul profesor francez explica, într-un curs pentru studenți ${ }^{\circ}$, la un nivel elementar și, deci, extrem de clar şi de accesibil, această distincție fundamentală pentru dreptul public. Pornind de la premisa că orice act normativ (reglementar) creează o situație juridică generală (impersonală, obiectivă), în vreme ce unul individual creează o situație juridică particulară (personală, subiectivă), cele două situații juridice (privite ca efecte/consecințe juridice ale celor două categorii distincte de acte administrative) se deosebesc fundamental din patru perspective diferite:

\subsubsection{Situația juridică generală vs. cea particulară}

Astfel, dacă prima este aceeași pentru toți indivizii care se află în aceleaşi condiții de fapt (și, ar trebui adăugat, oricine s-ar putea afla, din perspectivă teoretic-abstractă, în aceste condiții, de vreme ce, prin ipoteză, actul generator este „impersonal”), cea de-a doua este una specială, căci

9 Decizia nr. 1718/2013 a ÎCCJ, secția de contencios administrativ și fiscal, https://legeaz.net/spete-contencios-inalta-curte-iccj-2013/decizia-1718-2013.

${ }^{10}$ G. JÈZE, Cours de droit public. 1912-1913 (licence), M. Giard \& E. Briere Libraires-Editeurs, Paris, 1913, p. 9-17. 
dreptul sau obligația juridică aparține doar unuia (sau mai multor) indivizi anume indicați.

Altfel spus, actul administrativ normativ (reglementar) se caracterizează prin generalitatea normelor pe care le propune: obiectul său este definit a priori, fără a lua în considerare destinatarii, norma fiind edictată într-un anumit câmp de aplicare. Dimpotrivă, actul administrativ individual nu poate fi conceput în lipsa destinatarului său nominalizat ab initio, destinatar care, astfel, dobândește o situație juridică particulară.

\subsubsection{O situație juridică permanentă versus una temporară}

Dacă prima situație juridică subzistă un timp indefinit (căci puterea/prerogativa juridică născută dintr-un act normativ poate fi exercitată fără limită de timp, acest exercițiu neputând avea ca efect dispariția ei), cea de-a doua este una provizorie, căci dreptul ori obligația juridică cu caracter individual dispar prin exercitarea lor. Astfel, dacă dreptul de vot (ca drept fundamental, instituit prin reglementările generale) nu dispare după un anumit scrutin, obligația de plată a unui impozit stabilit printr-o decizie de impunere se stinge prin plata acestuia ${ }^{\mathbf{1 1}}$.

Sau, într-o exprimare mai des utilizată la noi, generalitatea normelor, specifică actului normativ, implică aproape întotdeauna, pe lângă caracterul impersonal al efectelor, vizând doar subiecți de drept definiți în mod abstract, (cu referire doar la calitatea lor), și caracterul de repetabilitate a aplicării (e.g.: o reglementare dintr-o hotărâre de guvern care stabilește contravenții în domeniul rutier se va aplica tuturor conducătorilor de autovehicule, prezenți și viitori, care vor săvârși o contravenție. Or, tocmai de aceea, actul normativ

\footnotetext{
11 ibidem, p. 12-15.
} 
nu se poate epuiza, aplicându-se repetitiv tuturor subiecților de drept care, în perioada de aplicabilitate a acestuia, intră sub incidența prevederilor sale). Dimpotrivă, actul individual, întrucât se aplică uneia sau mai multor persoane determinate, are vocație la epuizarea efectelor sale.

1.3.3 Aplicarea principiului „simetriei” (paralelismului de formă și competență) în cazul revocării/abrogării sau modificării actelor juridice normative, respectiv individuale

Conform principiului general al paralelismului de competență, respectiv de formă și procedură, un act administrativ poate fi modificat sau revocat/abrogat de către același (sau aceleași) organ(e) administrativ(e) care l-a (l-au) adoptat, urmând aceeași procedură, și respectând aceleași formalități. Aplicarea acestui principiu, în contextul prezentei analize, conduce la concluzia că natura juridică a actului administrativ de revocare/modificare trebuie să fie aceeași cu cea a actului revocat/modificat. Astfel:

a) un act administrativ cu caracter normativ nu poate fi revocat/modificat decât tot printr-un act normativ, nu și printr-unul cu caracter individual: de pildă, „Regulamentul Curții de Conturi” (act normativ) nu poate fi revocat sau modificat printr-o decizie a Curții de Conturi prin care se instituie măsuri de recuperare a prejudiciului adus bugetului local de o unitate administrativ teritorială, pentru că acest din urmă act cuprinde prevederi individuale aplicabile doar acelei unități administrativ teritoriale. Dar asta înseamnă și faptul că printr-un act individual al unui organ administrativ nu se poate deroga la un act normativ emis de aceeaşi autoritate publică, aşa cum vom dezvolta mai jos; 
b) Şi reciproca este valabilă: un act administrativ cu caracter individual nu poate fi modificat direct (de drept) printr-un act administrativ cu caracter normativ: o decizie prin care un funcţionar public primește un anumit premiu nu va fi modificată/revocată automat printr-un act normativ care înlătură posibilitatea acordării acelui tip de premiu, fiind necesară întotdeauna o altă decizie individuală prin care să se modifice/revoce raportul de drept administrativ între autoritatea publică și particular ${ }^{12}$.

Privit astfel, simetric, actul adoptat cu cel revocator/abrogator sau modificator trebuie să aibă aceeași natură juridică, fără a avea vreo relevanță ce anume sau cât se modifică din act: un act normativ poate fi abrogat/modificat tot printr-un act normativ ${ }^{13}$, chiar dacă se modifică o singură prevedere, iar un act individual - tot printr-un act individual, chiar și atunci când întreg actul ar fi revocat. Desigur, în mod legitim s-ar putea ridica întrebarea, dar de ce nu este posibil ca printr-un act individual (deci cu un destinatar nominalizat în cuprinsul actului) să se deroge de la un act normativ? Pe lângă prevederile art. 63 din L: 24/2000, citate la nota de la subsol de mai sus, o asemenea situație pur și simplu ar încălca prevederile art.

\footnotetext{
12 Această regulă în cazul actelor normative este cuprinsă și în dispozițiile Legii nr. 24/2000 privind normele de tehnică legislativă. Conform dispozițiilor art. 63, „pentru instituirea unei norme derogatorii se va folosi formula "prin derogare de la...", urmată de menționarea reglementării de la care se derogă. Derogarea se poate face numai printr-un act normativ de nivel cel puțin egal cu cel al reglementării de bază".

13 Astfel, în cazul actelor normative, modificarea lor este permisă în mod liber, pe motiv de oportunitate, nimeni neputând pretinde menținerea indefinită a tuturor prerogativelor decurgând dintr-un act normativ. Bunăoară, puterea electorală poate fi modificată (actul de identitate cu care se votează, arondarea alegătorului la o anumită circumscripție electorală etc.) în orice moment fără ca cineva să poată pretinde un drept dobândit în acest sens (G. JÈzE, op.cit., nota 10, p. 13).
} 
16 alin. (1) din Constituție (egalitatea în fața legii). Altfel spus, încă de la emitere actul derogator ar fi ilegal, de plano, pentru simplul fapt că este individual ${ }^{14}$, iar asta e de neacceptat într-un sistem ... de drept!

\subsubsection{Actul normativ/individual și posibilitatea de renunțare la beneficiul conferit de acesta}

În fine, ultima consecință a regimului juridic pe care G. Jèze o arată este și ea foarte ușor de înțeles: dacă declarația de renunțare a unui particular cu privire la un act administrativ normativ rămâne fără efecte ${ }^{15}$ cu privire la eficacitatea (starea - în vigoare sau nu) actului normativ, respectiv la obligația emitentului de a revoca actul pe motiv că un beneficiar nu dorește aplicarea sa, dimpotrivă, în cazul actelor individuale favorabile destinatarului, dacă acesta nu mai dorește ca actul să i se aplice poate renunța la beneficiul acestui act, situație în care organul emitent are obligația să îl revoce.

Rămâne în continuare să translatăm toate aceste chestiuni abstracte la materia, ceva mai concretă, a documentațiilor de urbanism.

\footnotetext{
14 De exemplu, de la o regulă potrivit căreia într-un anumit loc este interzisă staționarea autovehiculelor nu s-ar putea stabili o derogare individuală exclusiv în favoarea lui X (persoană nominalizată), chiar dacă am găsi o justificare în acest sens (bunăoară, aceasta este o persoană cu dizabilități). Singura ipoteză în care, într-un asemenea exemplu, derogarea ar fi legală, respectând prevederile art. 16 din Constituție, ar fi aceea făcută în favoarea tuturor persoanelor cu dizabilități (deci printr-un act normativ). Căci numai așa toate persoanele aflate în situații similare ar fi egali în fața normei respective.

15 Desigur, ne referim la actele normative care par a crea o situație mai favorabilă destinatarilor lor, căci nici nu se pune problema ca o persoană să poată „renunța” la o amendă sau la un impozit.
}

\section{3}


2 Aplicarea principiilor analizate mai sus la documentațiile de urbanism

Mergând de la principiile abstracte la categoria (mai concretă) a documentaţiilor de urbanism, vom porni în analiza noastră de la textele legale aplicabile acestora încercând totodată să identificăm sursele erorii jurisprudențiale (2.1) după care vom aplica cele patru criterii propuse de Gaston Jèze acestor acte administrative (2.2).

\subsection{Legea față în față cu jurisprudența}

Dacă după cunoștințele noastre nu există în prezent în doctrină vreun studiu în care să se susțină natura de act individual al documentațiilor de urbanism, situația apare și mai clar în același sens din analiza legislației incidente. Astfel, în primul rând ar fi de observat că legiuitorul a tratat complet separat cele două faze (cea „normativă” și cea „individuală”) în două reglementări diferite: dacă stabilirea regulilor de urbanism (care îmbracă forma documentaţiilor - PUG, PUZ, PUD, RLU, PMU) își are sediul materiei în L: 350/2001, aplicarea acestora prin intermediul actelor individuale (AC, AD) își regăsește fundamentele într-o altă lege, L: 50/1991 pentru executarea lucrărilor de construcții. Este primul indiciu în sensul caracterului normativ al documentațiilor de urbanism. În continuare, vom aborda însă pe de o parte normele care abordează unitar toate aceste documentaţii de urbanism (2.1.1), după care vom încerca să găsim sursele erorii jurisprudențiale (2.1.2). 


\subsubsection{Reglementarea comună a documentațiilor de urbanism}

Definite în comun, în cuprinsul dispozițiilor art. 44 din L: 350/2001, documentaţiile de urbanism (PUG, PUZ și PUD ${ }^{16}$ ) transpun, la nivelul localităților urbane și rurale, propunerile cuprinse în planurile de amenajare a teritoriului național, zonal și județean (art. 44 alin. [2]), având caracter de reglementare specifică și stabilind reguli ce se aplică direct asupra „localităţilor” și „părților din acestea” până la nivelul „parcelelor cadastrale” (s.n. Ov.P.), constituind elemente de fundamentare obligatorii pentru eliberarea certificatelor de urbanism (art. 44 alin. [3]). Având în vedere și definiţiile fiecărei documentații în parte (art. 46 din L: 350/2001 - PUG, art. 47 din L: 350/2001 - PUZ, art. 48 din L: 350/2001 - PUD) şi aplicând criteriul enunțat la punctul 1, al determinabilităţii persoanelor cărora li se aplică, concluzia principială ar trebui să fie în sensul că documentațiile de urbanism (PUG, PUZ sau PUD) trebuie să aibă aceeași natură juridică, aceea de acte administrative cu caracter normativ ${ }^{17}$.

Chiar terminologia utilizată de legiuitor ne îndreptățește să credem acest lucru: „reglementare”, respectiv „regulă” sunt două sinonime ale noțiunii juridice, mai des utilizate azi, aceea de „normă”. Să nu uităm că, atât

\footnotetext{
${ }^{16}$ Conform art. 45 din L: 350/2001.

$17 \mathrm{Cu}$ toate că există un curent jurisprudențial că PUD ar fi un act administrativ cu caracter individual, așa cum ne-am exprimat și anterior opinia (Ov. PODARU, Motivarea documentațiilor de urbanism (PUZ, PUD), piatră de temelie sau piatră de moară, în Curierul Judiciar nr. 2/2017, pag. 92-107), nu au existat, din cunoștințele noastre, discuții pe seama naturii juridice de act administrativ cu caracter normativ a planului urbanistic general sau zonal.
}

\section{5}


în doctrina (şi jurisprudența) franceză, din toate timpurile ${ }^{18}$, cât și în doctrina noastră interbelică ${ }^{19}$, în loc de noțiunea de „act normativ” era/este utilizată aceea de „act reglementar” sau „,act-regulă”. Lucru firesc, de altfel, căci, până la urmă, chiar în limbajul comun oricine înțelege că o regulă trebuie respectată de toți (cei cărora li se adresează, ar mai fi de adăugat). Deci „regula” este un act normativ.

În concluzie, cum documentaţiile de urbanism (PUG, PUZ sau PUD) instituie toate un set de reguli, (în cazul PUG și PUZ acestea fiind și scrise căci aceste documentații sunt însoțite, conform dispozițiilor art. 45 din L: 350/2011 şi de un regulament local de urbanism²0, în vreme ce, în cazul PUD, ele sunt doar desenate pe harta PUD - retrageri, căi de acces etc.). Ele sunt acte normative, căci, aşa cum vom vedea în continuare, aceste reguli nu sunt instituite exclusiv în favoarea/sarcina unei persoane determinate, pe

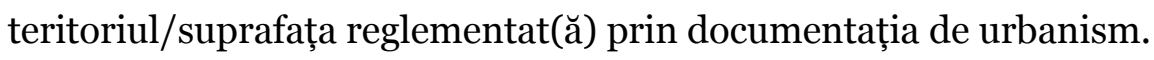

\footnotetext{
18 A se vedea doctrina franceză Bertrand SEILlER, Droit Administratif, Les sources et le juge, 2e edition Champs Universite, Paris, 2004, p. 78, Bertand SeILler, Droit administratif, 2. L'action administrative, 2e edition, Champs Universite, Paris, 2005, p 136.

19 A se vedea doctrina interbelică română Paul NEgulEscu, Tratat de drept administrativ român, Vol. II Organizarea administrativă a României, Partea I, ed. Atelierele grafice ale fundației „Voevodul Mihai”, București, 1930, p. 389; Constantin G. RARINCESCU, Contenciosul Administrativ, edițiunea a II-a, Ed. Universală Alcalay \& Co, București, 1936, p. 15, 18, 144, 246.

${ }^{20}$ Acest regulament, pentru întreaga unitate administrativ-teritorială (cel aferent PUG) sau pentru o parte a acesteia (cel aferent PUZ) cuprinde şi detaliază prevederile referitoare la modul concret de utilizare a terenurilor, precum și de amplasare, dimensionare și realizare a volumelor construite, amenajărilor și plantațiilor, materiale și culori, pe zone, în conformitate cu caracteristicile arhitectural-urbanistice ale acestora, stabilite în baza unui studiu de specialitate.
} 


\subsubsection{Sursele erorii jurisprudențiale}

Analizând jurisprudența care susține că documentațiile de urbanism tip PUZ sau PUD sunt acte individuale, dar și susținerile părților consemnate în considerentele unora dintre hotărâri, am ajuns la concluzia că, în principiu trei sunt motivele (acolo unde există într-adevăr asemenea motive clar expuse) care au condus unele instanțe la concluzia greșită a caracterului individual al documentațiilor PUZ sau PUD. Le vom analiza pe rând.

a) Transferul obiectului „determinabilităţii” de la persoane la parcele. Astfel, chiar dacă în unele spețe se face trimitere adesea la acest criteriu al „determinabilității” utilizat adesea și în jurisprudența instanței noastre supreme, acesta suferă o alterare la momentul aplicării sale in concreto: deși se admite că distincția se face prin determinabilitatea persoanelor cărora li se aplică (subiecți determinabili - act administrativ normativ, determinat - act administrativ individual), în acest loc fiind citată chiar lucrarea subsemnatului, atunci când este aplicat, în cazul PUZ sau PUD, raportul „determinabil/determinat” este transferat în mod subtil de la persoanele cărora le este aplicabil actul, la suprafața de teren vizată de PUZ/PUD: dacă terenul este determinat, cu o întindere relativ restrânsă, atunci şi actul administrativ ar fi unul individual, căci determinarea expresă a terenului ar permite identificarea proprietarului terenului, iar dacă actul este aplicabil, în concret, unui subiect care a putut fi determinat, actul ar fi unul individual.

Așa cum se poate observa, afirmația este greșită întrucât raportarea nu se face la determinabilitatea persoanelor asupra cărora documentaţia de urbanism își produce efectele, ci a terenului din zona studiată de PUZ/PUD. Este adevărat că indicarea expresă a terenului permite identificarea, în orice 
moment concret, a persoanei/lor căreia/cărora i/li se aplică documentaţia de urbanism (subiectul de drept care are un drept real asupra acestei parcele ${ }^{21}$ ), dar, aşa cum am arătat mai sus, generalitatea normelor nu exclude personalizarea efectelor: chiar dacă la un anumit moment, fiind cunoscută suprafața reglementată, se poate determina și persoana căreia i se aplică actul (în speță, proprietarul acesteia), actul rămâne unul „reglementar”, adică normativ, căci această persoană poate să fie o alta decât proprietarul terenului din momentul adoptării PUZ dacă operează o transmitere a dreptului real (fie se cesionează dreptul de proprietate asupra terenului, fie beneficiul autorizației de construire, o dată cu un alt drept real care implică dreptul la construire). Aşadar, dacă se vor transfera de către proprietarii terenurilor drepturile asupra cărora pot să dispună, în cadrul unor raporturi juridice de drept privat (în special care izvorăsc din actul administrativ cu caracter individual: autorizația de construire subsecventă), dobânditorii vor fi obligați să respecte regulile din PUZ. Prin urmare, un PUZ rămâne un act normativ chiar dacă, la un moment dat, există un singur proprietar al întregii suprafețe vizate, pentru simplul motiv că, la momentul adoptării lui, organul emitent nu avea cum să știe care sunt în mod exact persoanele față de care acest act urma să își producă efectele pe toată durata sa de valabilitate, pentru simplu motiv că nu le-a nominalizat.

Stabilirea documentației PUZ ori PUD ca fiind un act administrativ normativ sau individual nu poate avea drept criteriu întinderea suprafeței de teren care face obiectul acestei documentații de urbanism, acesta neputând fi

${ }^{21}$ Căci, conform dispozițiilor art. 1 din L: 50/1991, o autorizație de construire nu se poate obține decât de cel care este titularul unui drept real asupra unui imobil (teren și/sau construcții) identificat prin număr cadastral. 
nici măcar un criteriu „completator”: un asemenea criteriu ar fi, pe de o parte, imposibil de aplicat pentru că nu s-ar putea determina la ce limită de suprafață s-ar face tranziția între un act individual și unul normativ și, pe de alta, adesea într-o aparentă contradicție cu criteriul corect (determinabilitatea persoanelor), întotdeauna supus riscului alterării cu un criteriu pur cantitativ, situație care ar spori confuzia ${ }^{22}$. Așa cum am arătat mai sus, chiar dacă suntem în ipoteza unei singure parcele, cu un singur proprietar, actul va fi calificat tot ca act normativ căci dacă dreptul de proprietate s-ar transmite, cumpărătorului îi vor fi aplicabile aceleași reglementări din PUZ. Dimpotrivă, dacă am accepta drept criteriu caracterul „determinat” al terenului, ar însemna că și PUG-ul ar fi doar o sumă de acte individuale, căci el nu este altceva decât un set de reglementări pentru o sumă de parcele juxtapuse dar care pot fi privite în mod separat, „atomizat”(„parcelă cu parcelă”, fiecare dintre acestea putând avea, la un moment de referință, câte un singur proprietar); și în cazul PUG-ului se poate afirma că „beneficiarii” pot fi identificați prin chiar conținutul actului: verificându-se extrasul CF pentru fiecare parcelă de teren din intravilan, se pot identifica toți particularii cărora le este aplicabil planul urbanistic general.

\footnotetext{
${ }^{22}$ Astfel, până și cei tentați de dimensiunea cantitativă a distincției își vor pierde orice „busolă” atunci când ar avea de stabilit natura unui PUZ care reglementează o suprafață imensă de teren (să zicem un ansamblu imobiliar care urmează a fi edificat pe o suprafață de 100 ha, dar care are un singur proprietar), respectiv a unuia adoptat pentru $1.000 \mathrm{mp}$, dar unde se edifică un imobil cu 40 de apartamente, fiecare având un regim de proprietate periodică (time-sharing) - câte o săptămână pe an, existând, deci, câte 52 de „beneficiari” ai fiecăruia (peste 1.000 la întregul PUZ, aşadar). Desigur, concluzia este simplă, în ambele situații avem acte normative, pentru că (1) destinatarii nu sunt nominalizați expres și (2) suprafața reglementată nu reprezintă un criteriu (nici măcar subsidiar) de calificare, însă ne întrebăm, în această ipoteză, cum ar trebui să se completeze cele două criterii propuse? În general, dualitatea (pluralitatea) de criterii pentru a determina apartenența unui element la o categorie (din două) este periculoasă, căci distruge rigoarea științifică.
} 
Doar că sunt mai mulți, nu unul singur. Așa cum am mai susținut, dimpotrivă, PUG-ul nu este un act administrativ individual, ci normativ și nimeni nu pare, la acest moment, să susțină contrariul.

b) Utilizarea (măcar implicită) a criteriului cantitativ. În primul rând trebuie observat faptul că acest criteriu eronat a fost atins chiar în raționamentul de mai sus: cum parcela de teren are un proprietar determinat, destinatarului PUZ-ului care reglementează această parcelă este de asemenea determinat. Este un raționament greșit, aşa cum am arătat deja. O altă confuzie care pare să se fi făcut, strâns legată de cea de mai sus, constă în deplasarea caracterului „determinat” (specific actului individual) de la individ la calitatea pe care aceștia trebuie să o îndeplinească, pentru ca actul să li se aplice. Astfel, deși în cazul unui act administrativ normativ există o calitate determinată care permite identificarea particularilor cărora le este aplicabil actul (prin determinarea terenului), subiecții (destinatarii) sunt doar determinabili (oricine dorește să construiască în acea zonă), iar dacă subiecții sunt determinabili, actul este unul normativ (caracterul „determinat” al calității necesare - adică aceea de proprietar al parcelei pe care se aplică prevederile PUZ ori PUD - nu face ca actul să devină unul individual. De altfel, o modalitate de construcție a argumentelor în sensul: „persoanele sunt identificabile” - deci nu identificate - „prin chiar conținutul actului”, conduce tocmai la concluzia că PUZ-ul este un act normativ: particularii nu trebuie doar să fie identificabili prin conținutul actului, ci trebuie să fie identificați (nominalizați) expres.

Pe de altă parte, tot legat de acest caracter cantitativ, dar privit dintro altă perspectivă, un PUZ nu poate fi considerat un act individual nici dacă „cantitatea” derogărilor de la un alt PUZ ori de la PUG este una extrem de redusă (bunăoară, nu se modifică ansamblul regulilor de construire de pe 
parcela în cauză, ci numai una sau două asemenea reguli). Oare cum ar fi să considerăm un text, derogator de la un act normativ, având 100 sau 1000 de articole, ca fiind un act individual, pentru singurul motiv că modifică numai unul dintre articolele în cauză ${ }^{23}$ ? În mod evident, cantitatea regulilor modificate nu reprezintă un criteriu de distincție între actul normativ și cel individual.

\section{c) Identificarea unui fals „beneficiar” în cuprinsul} documentației de urbanism. Așa cum vom arăta imediat, acest „beneficiar” nu este singurul destinatar al documentației de urbanism. Vom analiza în detaliu această chestiune cu ocazia aplicării primului criteriu dintre cele propuse de G. Jèze.

\subsection{Analiza particulară a documentațiilor PUZ și PUD supuse criteriilor propuse de G. Jèze}

Întrucât controversele jurisprudențiale vizează în primul rând hotărârea de aprobare a documentațiilor PUZ și PUD, în continuare vom analiza, în concret, argumentele pentru care planul urbanistic zonal este un act administrativ cu caracter normativ. Planul urbanistic zonal este un instrument de planificare urbană de reglementare specifică, prin care se coordonează dezvoltarea urbanistică integrată a unei zone din localitate ${ }^{24}$, cuprinzând reglementări cu privire la (1) regimul de construire, (2) funcțiunea zonei, (3) înălţimea maximă admisă, (4) coeficientul de utilizare al terenului (CUT), (5) procentul de ocupare al terenului (POT), (6) retragerea clădirilor

\footnotetext{
23 La fel de hilar ca și susținerea că „Cele 10 porunci” reprezintă un act normativ, dar numai una dintre acestea, privită în mod singular, ar avea natura unui act individual: doar e una singură! (sic!)
}

${ }^{24}$ Art. 47 alin. (1) din L: 350/2001. 
faţă de aliniament și distanțele față de limitele laterale și posterioare ale parcelei, (7) caracteristicile arhitecturale ale clădirilor, (8) materialele admise $^{25}$. De asemenea, planul urbanistic de detaliu are caracter de reglementare specifică pentru o parcelă în relație cu parcelele învecinate care detaliază cel puțin: a) modul specific de construire în raport cu funcționarea zonei şi cu identitatea arhitecturală a acesteia, în baza unui studiu de specialitate; b) retragerile față de limitele laterale și posterioare ale parcelei; c) procentul de ocupare a terenului și modul de ocupare a terenului; d) accesele auto și pietonale; e) conformarea arhitectural-volumetrică; f) conformarea spaţiilor publice (art. 49 alin. (1) şi (3) din L: 350/2001).

Aplicând criteriul determinabilităţii persoanelor cărora li se aplică, se poate observa (mai ales din textele legale, dar și din conținutul concret al unor asemenea acte) că PUZ și PUD nu ar trebui să individualizeze în cuprinsul lor vreun beneficiar expres al actului administrativ, ele fiind aplicabil unor subiecți de drept determinabili prin calitatea lor de titulari ai unui drept real asupra oricărei parcele de teren aflate în zona reglementată de PUZ (de regulă, proprietarii unui asemenea teren, dar poate fi vorba și despre titularii unui alt drept real care permite construirea - superficie, concesiune, bunăoară). Altfel spus, niciun text legal nu indică faptul că o documentație PUZ sau PUD ar avea un beneficiar. Dimpotrivă, normele Legii nr. 50/1991 nu concep autorizația de construire în lipsa beneficiarului acesteia (art. 1, 5, 7 din lege sunt doar câteva exemple). Să trecem însă în revistă cele patru criterii analizate în prima parte a acestui studiu.

25 Art. 47 alin. (3) din L: 350/2001. 


\subsubsection{PUZ/PUD instituie o situație generală, iar nu una particulară, a} unei persoane determinate

Jurisprudența a ajuns la concluzia contrară în primul rând pentru că în unele hotărâri de aprobare a PUZ sau PUD apăreau unele persoane ca fiind „beneficiarii” actului în cauză. În realitate aceștia erau doar inițiatorii (și finanțatorii) acestei documentații de urbanism, dar nu și singura persoană față de care un asemenea act ar produce efecte juridice ${ }^{26}$. Concluzia este susținută cel mai simplu dacă PUZ-ul ori PUD-ul este privit comparativ cu autorizația de construire care se emite în baza regulilor edictate în planul urbanistic zonal: dacă regulile de construire cuprinse în autorizația de

${ }^{26}$ Astfel, potrivit art. 45 alin. (6) din L: 215/2001 a administrației publice locale, „Proiectele de hotărâri pot fi propuse de consilieri locali, de primar, viceprimar sau de cetățeni”, fără ca textul să facă distincție între hotărârile cu caracter normativ și cele cu caracter individual. În practică se găsesc suficiente HCL sau HCGMB care au un caracter normativ, dar care se adoptă la inițiativa unui cetățean oarecare: dacă o asemenea hotărâre este adoptată la inițiativa lui X, acest act își păstrează caracterul normativ, dacă subiecții de drept vizați de act sunt doar determinabili (iar X s-ar putea număra printre ei). Particularizând ideea, dacă în zona studiată de PUZ există mai mulți proprietari de terenuri, dar PUZ-ul a fost adoptat doar la inițiativa unuia dintre aceștia (așa cum adesea se întâmplă în realitate, căci nu toți cetățenii au spirit de iniţiativă şi resurse financiare pentru un asemenea demers, adesea costisitor), regulile din PUZ vor fi aplicabile și proprietarilor care nu au calitatea de inițiatori ai planului urbanistic zonal. Deci, în mod cert nu se poate pune semnul egalității între inițiatorul unei documentații de urbanism şi toți posibilii săi destinatari. De asemenea, nu se poate crea un criteriu artificial suplimentar prin reunirea celor două analizate anterior (criteriu constând în ideea că inițiatorul PUZ-ului este, totodată, şi beneficiarul acestuia), dacă niciunul dintre cele două (irelevanța calității de inițiator al unui PUZ, respectiv faptul că se poate determina un beneficiar concret, la un anumit moment, al actului) nu conduc la concluzia caracterului individual al documentației PUZ. Pe de o parte, așa cum am arătat, este irelevant cine are inițiativa adoptării PUZ-ului, iar, pe de alta, noțiunea de beneficiar în accepțiunea încetățenită în dreptul administrativ, presupune emiterea unui act în beneficiul unei persoane nominalizate expres în cuprinsul actului (beneficiu care îi aparține exclusiv). Faptul că, în mod accidental, investitorii PUZ beneficiază de regulile din PUZ (pentru că, la acel moment, aceștia au calitatea de proprietari), nu conduce la concluzia naturii de act individual al unei documentaţii PUZ de urbanism. 
construire au caracter particular, personalizat în favoarea unui beneficiar nominal, documentațiile PUZ sau PUD cuprind reguli cu caracter impersonal, cu aplicabilitate generală, repetată.

Astfel, autorizația de construire este întotdeauna un act administrativ cu caracter individual, întrucât nu numai că are beneficiarul nominalizat expres (de altfel, nu cunoaștem să fi susținut cineva contrariul, vreodată), ci, în plus, în perioada de valabilitate a autorizației de construire, doar beneficiarul nominal are dreptul de a construi (cesiunea autorizației de construire putându-se face după o procedură expres determinată de lege'27), pe când în perioada de valabilitate a PUZ-ului, oricine are un drept real asupra terenului și dorește să construiască trebuie să respecte prevederile acestuia. Dacă în timpul perioadei de valabilitate a autorizației de construire, operează un transfer al dreptului de proprietate asupra terenului, pentru a putea construi, cumpărătorului trebuie să-i fie cesionat și beneficiul autorizației (dreptul de a construi), aşa cum am arătat deja. În schimb, în cazul în care se schimbă proprietarul terenului care face obiectul PUZ-ului, dobânditorului îi va fi aplicabil PUZ-ul fără a-i fi cesionat și planul urbanistic zonal, acesta fiindu-i aplicabil automat întrucât, prin dobândirea proprietății ori a altui drept real, succesorul a dobândit calitatea cerută pentru a intra sub câmpul de aplicare al documentației de urbanism, cea de proprietar asupra terenului.

27 Art. 7 alin. (14) din L: 50/1991. Astfel, trebuie încheiat un act autentic notarial, înscris ulterior
în cartea funciară, din care să rezulte faptul că cesionarul (viitorul proprietar al lucrărilor
edificate) a dobândit un drept real care îi permite să construiască. Dar și în această situație, nu
oricine are dreptul să construiască, ci numai persoana expres nominalizată în actul de cesiune. 


\subsubsection{PUZ/PUD generează o situație juridică permanentă (caracterul} de „aplicabilitate repetată” specifică actelor normative), iar nu una temporară

Astfel, rămânând la raportarea documentaţiilor de urbanism la un act administrativ cu un evident caracter individual - autorizația de construire vom observa că aceasta din urmă are în mod cert un caracter epuizabil: întrun exemplu de școală, dacă construcția edificată în baza acesteia este demolată, total sau parțial, după efectuarea recepției finale (să zicem, pentru o credibilitate mai mare a exemplului, că a fost distrusă fortuit, într-un incendiu), nu se poate edifica un imobil identic în baza autorizației vechi, chiar dacă, prin ipoteză, aceasta ar mai fi încă în perioada de valabilitate: procedura de autorizare trebuie, așadar, reluată de la început, căci acest act individual nu are vocația de a fi aplicat repetat. În cazul documentațiilor PUZ ori PUD însă, (în același exemplu de școală) dacă ne situăm încă în perioada sa de valabilitate, pentru a se edifica un imobil identic cu cel distrus nu este nevoie de readoptarea unui PUZ identic, căci acesta nu are un caracter epuizabil, regulile din cuprinsul său aplicându-se în mod repetat ${ }^{28}$. Iar acest

\footnotetext{
${ }^{28}$ Un alt exemplu care confirmă caracterul neepuizabil și de aplicare repetată a PUZ-ului reiese din dispozițiile art. $47^{\wedge} 1$ din L: 350/2001. Conform acestui text legal, introducerea în intravilan se face prin PUG sau PUZ. Dacă PUZ ar fi act administrativ cu caracter individual, ar însemna că introducerea în intravilan ar avea un „beneficiar”, o parcelă fiind introdusă în intravilan exclusiv pentru proprietarul terenului (ceea ce ar contraveni dispozițiilor art. $48^{\wedge} 1$, din acelaşi act normativ, conform cărora, stabilirea limitelor intravilanului se face în funcție de nevoile de dezvoltare ale localităților din cadrul unei UAT), iar expirarea PUZ-ului ar determina scoaterea din intravilan a terenului. De asemenea, caracterul de act individual ar presupune că, dacă proprietarul terenului s-ar schimba, noul proprietar ar trebui să obțină un nou PUZ pentru intrarea în intravilan, ori să facă o cesiune notarială a efectelor PUZ. Or, raportat la efectele definitive și opozabile erga omnes ale introducerii în intravilan a unui teren, regulile cuprinse în PUZ nu se epuizează, ci se aplică în mod repetat oricărei persoane care intră în sfera lui de aplicare.
} 
lucru este ilustrat în practică, cel mai bine, prin solicitarea unui nou certificat de urbanism care va atesta faptul că regulile de construire în zonă/pe parcela construibilă au rămas neschimbate.

\subsubsection{Despre posibilitatea de modificare a PUZ și PUD prin acte normative}

Un alt argument, pentru care un plan urbanistic zonal este un act administrativ normativ, ține de faptul că L: 350/2001 permite ca acesta să deroge de la planul urbanistic general sau să modifice un alt plan urbanistic zonal (inclusiv cel referitor la zonele protejate ${ }^{29}$ ).

Conform prevederilor coroborate ale dispozițiilor 46 și 47 ale Legii nr. 350/2001, printr-un plan urbanistic zonal se poate deroga de la planul urbanistic general ${ }^{30}$. Este fără îndoială că planul urbanistic general are caracterul unui act administrativ cu caracter normativ. Prin urmare, fie că vorbim de un raport PUG-PUG, fie PUG-PUZ, principiul se aplică identic: actul modificator/derogator trebuie să aibă caracter normativ. La fel cum o modificare adusă PUG-ului printr-un nou HCL sau HCGMB (de pildă, ca urmare a admiterii unor plângeri prealabile sau a unor acțiuni de anulare parțială a PUG-ului) este cuprinsă într-o HCL sau HCGMB de natură normativă, la fel și o modificare adusă PUG-ului printr-un PUZ va fi și ea, tot

\footnotetext{
${ }^{29}$ Conform art. 54 alin. (3) din L: 350/2001, planurile de urbanism zonale sau de detaliu, care modifică părți din zone protejate, se pot finanța de către persoane fizice sau juridice interesate. $30 \mathrm{O}$ asemenea prevedere este cuprinsă, de pildă, în prevederile art. 46 alin. (5) din L: 350/2001: "Prin planul urbanistic general se identifică zonele pentru care se pot institui reglementări ce nu pot fi modificate prin planurile urbanistice zonale sau planuri urbanistice de detaliu și de la care nu se pot acorda derogări”. Per a contrario, în afara situațiilor expres reglementate de PUG, PUZ-ul poate cuprinde dispoziții derogatorii de planul urbanistic general.
} 
normativă. O concluzie contrară (că PUG-ul poate fi modificat printr-un act cu caracter individual) ar conduce și la încălcarea art. 16 din Constituție, despre care am vorbit mai sus: regulile din PUG (care pot fi mai restrictive) vor fi modificate doar pentru "beneficiarul" nominalizat al PUZ-ului (dacă ar exista o asemenea persoană), iar pentru toți ceilalți particulari, nu, nerespectându-se astfel egalitatea în fața legii și a autorităţilor publice. Iată, deci, o consecință deosebit de gravă a calificării unei documentații de urbanism ca fiind un act individual: întotdeauna această calificare echivalează cu admiterea, implicită, a ilegalităţii actului în cauză. Așadar, și din acest punct de vedere planul urbanistic zonal trebuie considerat că are un caracter normativ.

Aceeași concluzie trebuie să existe și în cazul PUD, chiar dacă prevederile art. 48 alin. (1) teza a II-a din L: 350/2001, potrivit cărora „Planul urbanistic de detaliu nu poate modifica planurile de nivel superior” ar părea că ne conduc la concluzia contrară. În realitate, această interdicție nu rezidă din natura juridică diferită a celor două acte administrative ci, pur și simplu pentru că legea a inserat o interdicție expresă în acest sens. Pentru că dacă ar fi existat într-adevăr o deosebire de natură juridică între PUD, pe de o parte, şi PUG şi PUZ, pe de alta, imposibilitatea de modificare ar fi funcţionat şi în sens opus, nici PUD-ul (act pretins individual) nu ar fi putut fi modificat prin PUG sau PUZ (acte normative). Or, nu credem că în jurisprudență ar putea exista o asemenea concepție în lipsa unei prevederi legale exprese în acest sens.

În final, mai trebuie subliniat și faptul că, admiterea concluziei greșite, a caracterului individual al documentațiilor de urbanism PUZ și PUD, ar conduce la concluzia că, de la momentul comunicării lor către beneficiari (căci de la acest moment actul produce efecte juridice) ele creează pentru aceștia 
un drept subiectiv „intangibil”, conducând la concluzia irevocabilităţii documentaţiilor de urbanism. Prin urmare, în ipoteza ilegalităţii acestora, raportat la prevederile art. 1 alin. (6) din L: 554/2004 ele nu mai pot fi revocate, ci numai atacate de autoritatea emitentă în contencios, timp de un an de la emitere (ceea ce, în sine, constituie o problemă). Dar, lucru şi mai grav, în lipsa stipulării unui termen în care ele să fie valabile, indiferent dacă sunt sau nu legale, ele nu ar mai putea fi modificate, nici măcar pentru viitor (inclusiv printr-un PUG), decât cu acordul particularului-beneficiar. Or, în mod evident, această concluzie ar fi una catastrofală pentru dezvoltarea armonioasă atât a localităților (în plan material, fizic), cât și a dreptului urbanismului (în plan teoretic, abstract). Numai normativitatea documentațiilor de urbanism permite modelarea regulilor urbanistice în pas cu vremurile, „dreptul dobândit” trebuind să fie recunoscut „beneficiarului” ca fiind născut numai din momentul obținerii unei autorizații de construire și consolidat din momentul începerii lucrărilor.

\subsubsection{Ineficacitatea renunțării la beneficiul PUZ/PUD}

Nu sunt multe de spus în acest loc: astfel, dacă în cazul autorizației de construire (ca, de altfel, în cazul tuturor autorizațiilor - prin excelență acte individuale) beneficiarul renunță la beneficiul conferit de act, formulând, totodată, cerere de revocare a acestuia (pe considerentul evitării unor cheltuieli ulterioare, cum ar fi diverse taxe, bunăoară), emitentul este obligat să revoce actul în cauză, neavând vreo putere discreționară în acest sens. În schimb, în cazul documentațiilor de urbanism, dacă aparentul „beneficiar” formulează cerere de renunțare la beneficiul PUZ sau PUD, autoritatea emitentă în niciun caz nu este obligată să revoce actul, păstrând o importantă putere de apreciere (specifică actelor normative) în acest sens.

\section{8}




\section{Dispariția principalei mize (practice) de calificare}

Un ultim argument: prevederile art. 64 alin. (3) din L: 350/2001, nou intrate în vigoare 31 !

Potrivit acestui text legal, „Litigïle generate de emiterea, revizuirea, suspendarea sau anularea hotărârilor de aprobare a documentațiilor de amenajare a teritoriului și de urbanism se soluționează de instanțele de contencios administrativ competente. Dreptul de a ataca hotărârile de aprobare se prescrie în termen de 5 ani de la data aprobării”. Fără a ne propune o analiză (cvasi)exhaustivă a acestuia, vom încerca să desluşim intenția legiuitorului: fără îndoială că acest text reprezintă o reglementare de excepție. Însă de la care regulă a fost instituită această derogare? De la cea a imprescriptibilității atacării actelor normative, prevăzută de art. 11 alin. (4) LCA sau de la termenul de 6 luni specific actelor individuale, reglementat de art. 11 alin. (1) LCA? O analiză a celor două situații posibile va conduce de asemenea la concluzia pe care o susținem: în concepția legiuitorului nostru, documentațiile de urbanism aprobate sunt acte normative.

a) Limitările temporale ale acțiunii în contencios administrativ îndreptate împotriva actelor normative sunt reglementate de art. 7 alin. (1^1) LCA coroborat cu art. 11 alin. (4) LCA: plângerea prealabilă poate fi făcută oricând de reclamant după care, la expirarea termenului de 30 de zile în care autoritatea sesizată cu plângere trebuie să răspundă ori, după caz, după comunicarea acestui răspuns, acțiunea în contencios administrativ de asemenea poate fi formulată oricând. Așadar, foarte puține constrângeri în acest caz. Prin urmare, dacă admitem că

${ }^{31}$ Așa cum a fost el modificat prin L: 151/2019, publicată în M.of.: 623, din 26 iulie 2019. 
termenul de 5 ani reprezintă o excepție de la imprescriptibilitate (justificabilă, pe fondul său, de necesitatea asigurării securității raporturilor juridice, de vreme ce, în temeiul acestor documentații de urbanism, se emit, ulterior, autorizații de construire, iar obiectul acestora - construcția - face adesea imediat obiectul tranzacțiilor specifice circuitului civil), corelația dintre norma generală și cea specială se face simplu: întrucât art. 64 alin. (3) nu face nicio referire la procedura prealabilă, aceasta se poate formula oricând, în temeiul art. 7 alin. (1^1) LCA, adică, în orice moment din termenul de prescripție de 5 ani. Desigur, dacă ținem cont și de prevederile art. 2532 pct. 7 C.civ. (cu care, în temeiul art. 28 din lege, materia contenciosului administrativ se completează de asemenea), pe durata soluționării procedurii prealabile termenul de prescripție de 5 ani se suspendă;

b) Limitările temporale ale acțiunii în contencios administrativ îndreptate împotriva actelor individuale sunt mai numeroase și, la o analiză mai atentă, imposibil de corelat cu prevederile analizate. Astfel, de la data la care cel vătămat a luat la cunoștință de conținutul actului (documentației de urbanism) are la dispoziție 30 de zile pentru a formula procedură prealabilă (căci acest termen nu a fost modificat prin reglementarea specială). Prin urmare, o primă întrebare: la ce bun un termen atât de lung (5 ani), pentru introducerea acțiunii, de vreme ce pasivitatea, care durează doar 30 de zile, conduce la inadmisibilitatea ulterioară a acesteia? Apoi, vom admite că acest termen, de 5 ani, îl înlocuiește pe cel de 6 luni, reglementat de art. 11 alin. (1) LCA, de vreme ce ambele sunt termene de prescripție. Dar și pe fondul problemei e greu de găsit o justificare rațională: de ce n-ar fi termenul de 6 luni suficient pentru acțiunea în contencios administrativ îndreptată împotriva documentaţiilor de urbanism, mai ales că acestea se bucură, potrivit legii, și de o publicitate semnificativă? 
Apoi, reglementarea specială nu reglementează nici vreun termen de decădere deci, strict juridic, cel de un an, reglementat de art. 11 alin. (2) LCA, a rămas neatins. Dar atunci termenul de prescripție de 5 ani n-ar mai avea nicio aplicabilitate de vreme ce termenul de decădere de un an s-ar împlini în toate situațiile cu mult înaintea acestuia. Iată, deci, suficiente argumente în sensul că legiuitorul a considerat aceste documentaţii de urbanism ca fiind acte normative: dacă le-ar fi considerat acte individuale ar fi trebuit să reglementeze mai în detaliu situația de excepție, pentru ca regulile derogatorii să fie aplicabile în mod efectiv.

O dată cu această reglementare însă, e foarte probabil că principala miză, a calificării documentațiilor de urbanism ca fiind acte normative ori individuale, să dispară și, o dată cu ea, inclusiv curentul jurisprudențial greșit, a cărui analiză am făcut-o mai sus. 